\title{
A HELYI ÁLLAMHATALMI SZERVEK A POLITIKAI ÁTALAKULÁS KÖRÜLMÉNYEI KÖZÖTT UDMURTFÖLDÖN 1991-1993-BAN
}

\author{
(The Local Governmental Organisations under Circumstances of \\ Political Transition on Udmurtland in 1991-1993)
}

\section{MARINA V. YARNYKH}

Kulcsszavak:

Udmurt Köztársaság politikai átalakulás hatalom helyi tanácsok

A tanulmány az Udmurt Köztársaságra fókuszálva mutatja be a nyolcvanas évek végén-kilencvenes évek elején a Szovjetunióban lejátszódott politikai folyamatok következtẻben fellépö hatalmi átrendezödést, a helyi tanácsok szerepének, jelentöségének visszaszorulását, hatalomvesztésének folyamatát.

Az 1980-as évek végén lejátszódó politikai folyamatok jelentős szerepet játszottak a központi és a helyi államhatalom újjászervezésének folyamatában. Az első politikai intézkedéscsomagnak köszönhetően az SZKP-s struktúrákat kivezették a határozathozatal és irányítás sémájából, megváltoztatva ezzel az állami élet algoritmusát, miáltal a határozathozatal összes kihívása és felelỏssége, illetve a végrehajtás funkciói a tanácsi államhatalmi kormányzati szervekhez kerültek át.

A tanácsoknak, miután a reformok következtében jelentősen eltávolodtak a szovjet típusú államhatalmi szervek részére tájékozódási pontul szolgáló modelltől, vagyis Karl Marxnak „A mủködő testületekről” írott ideálképétől, nem sikerült teljes mértékben megvalósítaniuk saját hatalmi és irányítási tôrekvéseiket.

$\mathrm{Az}$ 1991. augusztusi események megváltoztatták az ország politikai irányát, és lerakták az államhatalom rendszere strukturális megváltozásának alapjait.

A képviseleti hatalom szovjet formáinak mủködése 1991-1993-ban legfôképpen azon átalakítási kísérletekkel függött össze, amelyek az elnöki típusú irányítási rendszert és az önkormányzatiság alapjait alakították ki. Egyes kutatók véleménye szerint azonban a tanácsokban rejlö potenciális lehetőségek messzemenóen nem lettek kimerítve (pl. Osadcij 1996, 74; Ivancenko 2001; Koveschnikov 2002).

Az elnöki struktúra keletkezése hozzájárult a korábbi szovjet államrend lerombolásához, hiszen ezen új rendszer objektíve magához vonzotta a hatalmi kiváltságokat, és egyre több végrehajtó funkciót szerzett meg az államban.

Az elnöki hatalom intézményének programtervezete az 1990. márciusi Központi Bizottsági plénumon került elfogadásra, ahol M.Sz. Gorbacsovot ajánlották a Szovjetunió elnöki posztjára. Új „,peresztrojka ötleteket” tárgyalt meg a Szovjetunió népi küldöttjeinek 3. kongresszusa 1990 márciusában. A Kongresszus végül a Szovjetunió elnöke posztjának létrehozásáról döntött. 
A hivatalos állásponttal szemben, miszerint a hatalmi vákuum létrejötte az elnöki poszt, a központi kontrol és a szövetségi szintü központ erösítésének szükségszerüségét indokolta, olyan ellenvélemények is napvilágot láttak, amelyek annak adtak hangot, hogy az elnöki modell semmilyen módon nem illeszkedik a szovjet típusú irányítási formákba, ezek alapján bevezetése semmivel nem magyarázható, öngyilkos döntés volt a szovjethatalom számára (Tereschenko 1997).

A megreformált szovjethatalom kénytelen volt a következő transzformáció útjára lépni azt követően, hogy meghatározó kapcsolatait elveszítette, ennek ellenére kevéssé volt összhangban az elnöki hatalom intézményével. J.J. Frojanov (1999) szerint ezen ellentmondás alapozta meg a végrehajtó hatalom és a népképviseleti szervek konfliktusát.

A szovjet politikai rendszer transzformációjának befejező szakaszát már az OSZSZSZK szintjén határozták el, amely a Szovjetunió jogutódja lett. A Szovjetunió Alkotmányának az SZKP állami és társadalmi vezetô szerepét jogilag deklaráló 6. cikkelye hatályon kívül helyezését, az Oroszországi Föderáció szuverenitásának kikiáltását és törvényei szövetségi törvények feletti prioritásának térnyerését követően a köztársaság népképviseleti szervei - a Kongresszus és a Legfelsőbb Tanács - az ország területén a néphatalom kizárólagos letéteményesei lettek. E szervek háttere két részre volt osztható: részint a B.N. Jelcin körül csoportosuló antikommunista szárnyra, amelyet a társadalom széles körben támogatott (mindenekelött a nagyobb városokban és nagyvárosokban), továbbá a kommunista erőkre.

E politikai harc logikája késztette B.N. Jelcint egyre élesebb konfrontációra a szövetségi központtal és M.Sz. Gorbacsovval; e konfliktus során keletkezett az elnöki pozíció bevezetésének gondolata. A Legfelsőbb Tanács 1991. április 24-én elfogadta az OSZSZSZK elnökéről szóló törvényt. Ilyen módon a hatalom az Oroszországban megszokott módon az Oroszországban elfogadott, vagyis a perszonalizált és egy személyben megjelenő formához tért vissza (Koveschnikov 2002).

$\mathrm{Az}$ elnöki pozíció tehát Oroszországban politikai harc közben és annak hatására keletkezett, válasz volt a tanácsok funkcionális cselekvőképtelenségére, miután azok elveszítették legfóbb hatalmi támaszukat, a hanyatló SZKP-t. Az új hatalom egyidejủleg kiélezte a meglévő ellentéteket, amelyek abból következtek, hogy egy államszervezeten belül kettős hatalom létezett egymással szemben: egyik oldalon az új elnöki hatalom (elnököt Oroszország lakossága is választott), föderalizmus, a hatalom szétválasztásának és kölcsönös korlátozásának elve, másik oldalon a régi hatalmi rend a szovjetek erös hierarchiájával és az összes hatalmi funkcióban élvezett monopóliumokkal. Az új struktúra ilyen módon gyakorlatilag helyreállitotta a tanácsokra jellemző alapvető ellentmondást. A korábbi konfliktus, amely a népképviselök tanácsának jogi teljhatalma és az SZKP hatalmi monopóliuma között feszült, áttranszformálódott a Legfelsőbb Tanács és az elnök síkjára. A küzdelem egyre élesebb formákat vett fel arra tekintettel, hogy immár nem egy legitim (választott szovjetek) és egy illegitim (SZKP) hatalom között ment végbe, hanem egyaránt választott és legitimált két hatalmi intézmény között. 
Az országban lévő új hatalom szuverenitásra törekvése és hatalmának intézményesítése a politikai helyzet változását idézte elö, amely meghatározta az állami átalakulások irányát Udmurtföldön. A pontos stratégia a köztársasági vezetésben is hiányzott, erröl tanúskodnak az Udmurt Köztársaság Legfelsőbb Tanácsának ingadozásai az elnöki és a hatalmi struktúrák között.

Az Udmurt Köztársaság Legfelsöbb Tanácsának 8. ülésszaka 1991. október 10-én elfogadta „A Udmurtföldi Köztársaság állami hatalmának és irányításának reformjáról" szóló törvényt, amely az Udmurtföldi Autonóm Szovjet Szocialista Köztársaság 1978-as Alkotmányának számos rendelkezését hatálytalanította. Az udmurt legfelsőbb tanácsi képviselők a központi és a szomszéd tagköztársaságokban végbement reformok tapasztalatai alapján már akkor alapvetően az elnöki hatalom kiépítése mellett törtek lándzsát. V.J. Gelman elemzö szerint az elnöki intézmény létesítését a regionális vezetök többsége úgy tekintette, mint a „valódi” államiság attribútumát, részint, mint a regionális hatalom és a köztársaság megerősítésének eszközét a Szovjetunió és az OSZSZK szerveivel a régió erőforrásainak ellenőrzésért folyó alkuban. Az „Udmurtföldi Köztársaság állami hatalmának és irányitásának reformjáról” szóló törvény 1. cikkének első pontja arról szól, hogy „létre kell hozni az Udmurt Köztársaság elnökének tisztségét, aki a legmagasabb közjogi méltóság, egyidejüleg a végrehajtó hatalom feje, aki közvetlenül vezeti az Udmurt Köztársaság kormányát." (Zakon 1991) A végrehajtó hatalmat a köztársaságban a Legfelsőbb Tanácsnak kellett volna megtestesítenie. Az elnöki köztársaság aktív hívei abban az időben a küldöttek egyes csoportjai voltak, az udmurtok és a „Demokrácia Udmurtföldön"-ben csoportosuló személyek (Bechterev, S.L.-Bechterev, L.N. 2001, 106). A kialakult körülmények miatt az UK Legfelsőbb Tanácsát mandátumának lejárta elött feloszlatták, és 45 küldöttbỏl szakmai alapokon létrehozták a Kis Tanácsot.

Az alapvető hatalmi intézmények, szerveik és tisztviselőik között a hatalmi hatáskörök átcsoportosításáért indult harc számos elképzelést hozott napvilágra. Közöttük például az Udmurtföldi Köztársaság Legfelsőbb Tanácsa bizottságának azon terveivel, amelyek a népi küldöttek tanácsa munkájának kérdéseivel, a kormányzat és az önkormányzatiság kérdéseivel (M.I. Nazarov), illetve a Udmurt Köztársaság Legfelsöbb Tanácsa Elnöksége jogkörének kiszélesítésével kapcsolatosak. A bizottság tervei között szerepelt a törvényhozással kapcsolatos is (P.N. Dianov), amely a felszabadult 45 képviselöből szakmai alapon javasolta létrehozni a Kis Tanácsot. A gazdaságfejlesztésért és tervezésért felelős O.J. Botkin megbízott elnök által vezetett bizottság javaslatában az szerepelt, hogy a Udmurt Köztársaság minisztertanácsa elnökének elnöki hatáskört szükséges biztosítani, amellett, hogy egy 25-30 képviseiőböl álló Kis Tanács kerül létrehozásra, melynek ülésezési gyakoriságát, továbbá elnökségének hatáskörét csökkenteni kell (Scukin 1995).

Ez időben az udmurt nemzeti elit is aktivizálódott. Az 1991. november 22-23-i, szövetségi szintü össz-udmurt első kongresszus támogatta az Udmurt Köztársaság Legfelsöbb Tanácsának azon határozatát, amely ,az elnöki irányítási forma bevezetéséről szól" (és arról is, hogy az elnöknek az udmurt és orosz nyelvet egyaránt 
beszélnie kell), illetve amely a kétkamarás Legfelsőbb Tanácsról szólt, ahol is a köztársaság és a nemzetiségek kamarája egyaránt megtalálható (Materialy 1991).

Az 1991 augusztusa után alaposan demoralizált baloldali frakció kiállt a szovjet hatalmi rendszer megörzése mellett, és természetesen ellene volt az elnöki forma és a szakmai parlament bevezetésének. Az ipari igazgatóság szintén elvetette az elnöki hatalmi variánst, ebben egy húrt pengetve a kommunistákkal.

A javasolt törvénytervezetek nem kapták meg a küldöttek többségének szavazatát. Az elnöki hatalomról szóló kérdés tehát 1991-ben megoldatlan maradt Udmurtföldön, ami azzal magyarázható, hogy az ország még nem volt kész ilyen horderejü politikai váltáshoz. A lakosságnak nem voltak elképzelései az elnöki hatalmi intézményről, következésképpen a saját pozíciójáról sem. A közvéleménynek tehát Udmurtföldön 1991-ben nem sikerült a kérdésben mozgató erővé válni. Ami az udmurt politikai elitet illeti, körükben sem volt egység. A demokraták az elnöki hatalom mellett törtek lándzsát, miután felfogták a hatalom cselekvőképtelenségében rejlö veszélyeket. A saját pozíciójukat megörizni kívánó konzervatív politikusok természetesen a meglévó rendszert kívánták fenntartani. Jóllehet, a személyes ambíciókon kívül - valamennyi csoport „,saját magának” kívánta átépíteni a hatalmi struktúrát - voltak objektív okai is a hatalmi intézmények megreformálásának. Az elnöki struktúra létrehozásáról szóló, 1991-ben elhalasztott kérdés meghatározó lett a köztársaság politikai fejlődésében a következő 10 évben.

Az állami szerveket érintö, központi és köztársasági szinten végbemenő reformok a helyi hatalmi szervekben is megjelentek. A helyi tanácsok átszervezése folytán e szervek a helyi önkormányzat hatékony szerveivé váltak az 1990. április 9-én elfogadott, „A helyi önkormányzatok és a helyi gazdaság közös kezdeteiről a Szovjetunióban” szovjet és az 1991. július 6-án elfogadott „A helyi önkormányzatokról az Orosz Föderációs Szovjet Szocialista Köztársaságban"2 szóló szovjet-orosz törvénynek megfelelöen.

A helyi önkormányzatokat az, ,állampolgárok által az összes helyi jelentőségü kérdés közvetlen vagy választott szervek útján való megoldása céljából létrehozott önszervezödés"-ként tekintették. Az önkormányzat megvalósítási mechanizmusában részt vettek a helyi tanácsok, a lakosság területi társadalmi önkormányzati szervei, a helyi referendumok, lakossági gyúlések, az állampolgárok összejövetelei és a közvetlen demokrácia-gyakorlás egyéb formái is. A helyi önkormányzat alapvető elvei között került meghatározásra az, hogy a tanácsok tevékenységében a helyi és állami érdekeket egyesíteni kell. A helyi önkormányzatiság iránti igény törvényben való megerósítése - a különbözó lakossági érdekekből és az adminisztratív területi egység különlegességéból kiindulva - ahhoz vezetett, hogy a helyi tanácsok különböző szintjei között a funkciókat elkủlönítették. Azt is egyre inkább hangsúlyozták, hogy az önkormányzati szervek függetlenségének és önállóságának szilárd pénzügyi és gazdasági alapokra kell támaszkodnia.

A helyi gazdaság alapja azon kommunális tulajdon volt, amely magában foglalta mindazon vagyontárgyakat, amelyeket a helyi önkormányzat szerveihez tartozó számlák terhére hoztak létre, vagy vásároltak meg, továbbá mindazon vagyont, 
amelyet a szövetségi és köztársasági szervek térítésmentesen adtak át a helyi önkormányzatoknak. Eközben a kommunális tulajdon az állami tulajdon egy fajtája volt (Begunov et al 1999, 20), amelyet a felettes állami szervek adtak át az önkormányzat szerveinek vagyonkezelés céljából. A helyi tanácsoknak lehetőségük volt arra, hogy kérdést tegyenek fel arra vonatkozóan, vajon tulajdonukba átadnak-e olyan vállalatokat és intézményeket, amelyek egyéb tulajdonban állnak, azonban a lakosság szociális-kulturális igényeinek kielégítésében fontos szerepet játszanak. A helyi tanácsok illetékességi területén elhelyezkedő vállalatokkal való kapcsolatokat a törvény szabályozta. Valamennyi vállalat köteles volt saját eszközeinek egy részét a helyi költségvetés alakításába bevonni, ezzel átadva nyereségük egy részét, továbbá, terveiket a helyi tanáccsal kötött szerződésben meghatározott részben szabadon nem alakíthatták.

A helyi tanácsok a saját hatáskörükben - a létezö anyagi-pénzügyi forrásokból kiindulva - önállóan dolgozták ki és hagyták jóvá a terület szociális-gazdasági fejlődésének terveit. A helyi önkormányzat és a gazdaság szereplöinek anyagitechnikai ellátása olyan módon jelent meg a szerződéses viszonyokban, ami a gazdaság szereplőinek teljes gazdasági önállóságát biztosította.

Azt, hogy a tanácsok - elsősorban a városiak - realizálhassák is a megszerzett hatásköreiket, visszafogta gazdasági bázisuk gyengesége, a tanácsok érdekében müködő gazdaságok korlátozott száma, a köztársasági hatalmi szervek és a tanácsok hatáskörének felosztatlansága az önkormányzati tulajdon kapcsán, melynek folytán nem nyílt lehetőség arra, hogy a költségvetésben tartalékot hozzanak létre stb. Még jobban súlyosbították a helyi tanácsok helyzetét az 1992-es radikális gazdasági reformok, amelyek az akkor hatályos finanszírozási elv szerint kényszeríttették öket továbbmüködni. Így például Izsevszk városában a városi tanács 1992-es költségvetésének elfogadása formálisan zajlott le, mivel a költségvetés jóváhagyására csak 1992 legvégén került sor ${ }^{3}$. A költségvetés összeállitásának nehézsége azzal magyarázható, hogy a vállalatoknak nem voltak pénzügyi tervei, a piaci konjunktúra állandóan változott, ezen tendenciák pedig nem tették lehetővé a vállalatok gazdasági eredményének megalapozott prognosztizálását, ezáltal a költségvetési bevétel, továbbá - az állandóan növekvő árak mellett - a költségvetési kiadások elórejelzését. A levonások normatíváinak negyedévenkénti változása a korábban a helyi költségvetésbe befolyó rendszeres jövedelmek után azt hozta, hogy a városi tanácsok végrehajtó bizottságai kénytelenek voltak a pénzügyminisztérium pénzügyi osztályain összeállított költségvetéseket negyedévenként megvédeni. Emellett, ahogy megjegyezte azt L.P. Martyinova, Izsevszk városi tanács VB városi pénzügyi osztályának vezetöje és V.J. Zaszüpkin, a városi tanács képviselője: az Oroszországi Szovjet Köztársaságnak az „OFSZSZK helyi önkormányzatairól” szóló törvénye alanyi jogként határozza meg a helyi tanácsok számára, hogy önállóan dönthetnek a költségvetésükröl, vagyis a gyakorlatban a felülről diktált költségvetést és a normatívákat saját rendszeres jövedelmeikkel helyettesíthetik.

A helyi hatalmi szerveknek az új gazdasági formák létrehozására irányuló kísérletei - amelyek a piaci viszonyokra történő átmenettel jöttek létre - a tanácsok 
hagyományos munkaformáival párosultak. Noha 1991-ben és 1992-ben a köztársaságban 6402, illetve 5832 tanács volt, közülük a választások eredményei alapján $33,4 \%$ (2138), illetve 47,4\% (2767) állt össze megfelelö létszámban ${ }^{4}$. Az állampolgárok véleményének figyelembe vétele a levelek és panaszok munka közben való feldolgozása, illetve a lakossági fogadóórák során történt.

Az Izsevszki Városi Tanácshoz 1992-ben különböző fórumokról 1292 beadvány érkezett, amelyek feldolgozásra kerültek, és amelyekben ügydöntő határozat született. Az állampolgárok privát kérdéseivel 158 föt fogadtak személyesen. Ezen ügyek közül 71 kérdést pozitívan megoldottak, 17 ügyet elutasítottak, 20-at tisztáztak, míg 40-et a végrehajtó szervekhez és a munkahelyekre irányítottak ${ }^{5}$. Az írásbeli megkeresések és a fogadóórák során az állampolgárokat érdeklỏ legfőbb kérdések a lakásproblémák, a telefonhálózat kiépítése, a városi ökológiai kérdések és a földosztás voltak.

A helyi tanácsok mint önkormányzati szervek pénzügyi fizetésképtelenségüket megerősödö politikai aktivitással kompenzálták 1991-ben, miután a hatalomért a létező összes szinten megerősödött harc a köztársaság városi tanácsait sem hagyta érintetlenül. Az Izsevszki Városi Tanácsban a 8. ülésszak munkája közben (1991. november 21-26.) történt hatalomváltás, ugyanis felmentették a városi tanácselnöki funkciója alól V.E. Ljalint, az új elnök pedig V.V. Balakin lett ${ }^{6}$. A Votkini Városi Tanács 1991. decemberi ülésszaka azzal végzỏdött, hogy az Elnökség az elnök vezetésével kollektíven lemondott. Visszavonták a megbízását N. Potincev elnöknek, J. Celouszov elnök-helyettesnek, majd az összes állandó bizottság elnökének is?

A politikai élet és a gazdasági rendszer átalakulása nyomán felmerült a képviselötestületi munka minőségének és professzionalizmusának problémája. A városi tanács strukturális módosítása az lzsevszki Városi Tanács 2. ülésszakának fỏ napirendi kérdése volt. Az Izsevszki Városi Tanács egy sor másik orosz város Szverdlovszk, Kaluga, Perm, Krasznojarszk, Krasznodar, Naberezsnüje Cselni tapasztalatát figyelembe véve arról határozott, hogy egyes állandó bizottságok elnökeit szakmai munkára szabadítja fel ${ }^{8}$.

A helyi önkormányzat mint önálló és az állami hatalomtól leválasztott kormányzati forma alkotmányos megerősitése nem egy-kettőre történt. Az Alkotmány új változatának 137. cikkelye szerint a népi küldöttek tanácsai a vidék, a terület, az autonóm terület és az autonóm körzet szintjén még mindig az állami hatalom helyi szervei maradtak. Kerületi, városi, települési és községi tanácsokat nem említett e törvényhely. Ez azonban nem jelentette azt, hogy az említett tanácsok ne lennének az állami hatalom helyi szervei. A 85. cikkely szerint ugyanis valamennyi tanács az Oroszországi FSZSZK Küldöttgyủlésétől és Legfelsöbb Tanácsától a települési és falusi tanácsokig bezárólag - ,az OFSZSZK államhatalmi-népképviseleti szerveinek egységes rendszerét alkotják." (Avakjan 1996, 5-6)

Az 1991. május 24-i reform folytán a közigazgatási szakemberek kritikái hatására a helyi tanács végrehajtó bizottság elnevezését a „helyi közigazgatás” kezdte felváltani. E szinten az elvi újdonság abban állt, hogy a végrehajtó bizottságnak, amely korábban a helyi tanácsnak és a magasabb szintü végrehajtó és rendészeti szerveknek beszámolási kötelezettséggel tartozott, immár a helyi tanács rendszerében nem 
volt megfelelő szerve. A helyi közigazgatás vezetői, akik a helyi tanács V.B.elnököket felváltották, az egyszemélyi vezetés elve mentén működtek. J.N. Trofimova (2002) kutató szerint a végrehajtó hatalom alapstruktúráinak a tanácsok kontrollja alól való kivezetése azt a célt szolgálta, hogy megakadályozta a képviseleti szervek egységes, szovjet típusú alá-fölérendeltségi rendszerének kialakulását.

A helyi végrehajtó hatalom restrukturálását nem követte a müködő helyi tanácsok szintjén átalakítás. Egyetlen olyan intézkedés volt csak, amely hozzájárult a tanácsok professzionalizálásához, méghozzá az az 1991 decemberében elfogadott törvény, amely bevezette a kis tanácsok intézményét - folyamatosan müködő szerveket, amelyek létszáma a „nagy” tanácsok képviselötestületeinek egyötödéig terjedt. E kisebb szervek az ülésszakok között pontosan meghatározott területeken látták el a tanácsok funkcióit, leszámítva a költségvetési és személyi kérdéseket. Az Udmurt Köztársaság törvényhozásában kis tanácsok választását csak kerületi és városi tanácsok szintjén tervezték, települési és községi szinten nem".

A Köztársaság életében 1992-ben robbant ki az első komoly politikai konfliktus az UK Legfelsőbb Tanácsának 9. ülésszakán. A Tanács ekkor 5 hétig ülésezett, melynek során törvényjavaslatok egész sorát tárgyalta meg és fogadta el, köztük a helyi hatalmi és kormányzati szervek struktúrájának szabályozásáról szóló javaslatot. Az UK Legfelsőbb Tanácsa határozata alapján a helyi tanácsoknak joguk lett arra, hogy a végrehajtó bizottság elnökei a közigazgatási vezető hatáskörét gyakorolják. Ezen joggal a helyi tanácsok több, mint 90\%-a élt. Ezen kívül, míg 1992 elején a tanácsok több, mint felében - köztük városi tanácsokban - a tanácselnök és a V.B.-elnök tisztjét azonos személy töltötte be, a Legfelsőbb Tanács határozatának elfogadását követően ezen lehetőség már csak a települési és községi tanácsok részére maradt fenn ${ }^{10}$.

Az UK Legfelsőbb Tanácsának 9. ülésszakán nem hoztak döntést azon kérdésben, hogy a felszabaduló képviselőkből kis tanácsokat vajon kell-e létrehozni. A javaslat olyan tiltakozást váltott ki a képviselők radikális-demokrata részéről, hogy azok kivonultak az ülésteremböl, ezáltal döntésképtelenné téve az ülést a szükséges létszám hiánya miatt (Scukin 1995, 7). A radikálisok ezen ülésszak alatt a Legfelsóbb Tanácsot müködésképtelenséggel és munkája alacsony hatékonyságával vádolták. Az UK Legfelsőbb Tanácsának állandó bizottságai - amelyekben összesen 13 felmentett képviselő ${ }^{11}$ müködik - nem tudtak megbirkózni a törvényhozási munkák megnövekedett terjedelmével. Azon kívül a határozatok elfogadását megnehezítette a rendszeres képviselöi hiányzás és emiatt a döntéshozatalhoz szükséges létszám állandó veszélyben forgása ${ }^{12}$. Hasonló helyzet a városi tanácsok munkájában is elöállt ${ }^{13}$.

A hatalmi harccal elfoglalt köztársasági állami szervek nem hatékony múködése, valamint az egyre mélyülő gazdasági válság napirendre hozta a Köztársaságban is a hatalmi szervek megreformálásának kérdését. A kérdések megválaszolását bonyolította az 1992-1993-ban az Oroszországi Föderáció szintjén végbement alkotmányos válság, melynek alapja az Oroszországban lejátszódott ellentmondásos átalakulás volt, amely folytán az országban két egymást kizáró rendszer müködött: a szovjet és 
TÉT XXI. évf. 2007 - 4

az elnöki. A végrehajtó és a törvényhozó hatalom küzdelmének színtere az Oroszországi Népi Küldöttgyülés lett.

A központi hatalmi szervek ellentétei a teljes 1992-es évben hatást gyakoroltak az Udmurt Köztársaság politikai életére. Egyrészröl politikai harc alakult ki a köztársasági parlamentben a kormány lemondatása kérdésében. A számtalan lemondatási kísérletre az tett pontot, hogy 1992. november 27-én a Köztársaság Legfelsőbb Tanácsa elégtelennek itélte N.E. Mironov kormányának tevékenységét, de a lemondás ekkor sem következett be. Másrészről láthatóvá váltak a helyi hatalom struktúrájának és mechanizmusának problémái, különösen a városi önkormányzatok szintjén. A városon belüli irányítás, valamint a város és a magasabb szintủ szervek irányítási hatáskörei elkülönítésének javaslata megjelent az Izsevszk város Szervezeti és Mủködési Szabályzatának keretein belül, melynek tervezetét a városi tanács 10 . ülésszakán javasolták megtárgyalásra.

Az Udmurt Köztársaságban a politikai reformok további menetére nagy hatást gyakoroltak az 1993. szeptember-októberi moszkvai események. Az Oroszországi Föderáció elnöke és az Oroszországi Föderáció Legfelsőbb Tanácsa közötti összetüzés az 1400. számú (1993. IX. 21.), ,az Oroszországi Föderáció szakaszos alkotmányos reformjáról" szóló elnöki rendelet kiadásához vezetett. A Rendelet elrendelte a Népi Küldöttgyưlés és a Legfelsőbb Tanács tevékenységének beszüntetését, egyúttal december 11-12-re választások tartását írta ki, melynek során az új föderatív népképviseleti szervek kerültek megválasztásra, vagyis egy kétkamarás parlament, amely a Szövetségi Tanácsból és az Állami Dumából áll, továbbá az Orosz Föderáció új Alkotmánya került elfogadásra.

A szeptember-októberi válság idején (Rjabov 1994), vagy ahogyan jogosan megjegyzi Sz. Scukin $(1995,38)$, a moszkvai „nomenklatúra-forradalom” drámájának kibontakozása idején az UK Legfelsöbb Tanácsa 3 ülésszakot tartott, ahol elítélték az orosz elnök, B.N. Jelcin alkotmányellenes tevékenységét, és határozatot hoztak arról, hogy az elnök rendeleteinek hatálya nem terjed ki a Köztársaság területére.

A végrehajtó és törvényhozó hatalom politikai ellentéteinek fegyveres megoldása 1993 októberében az elnöki struktúrák győzelmét és a szovjethatalom teljes összeomlását hozta. Felszámolták a szovjetrendszer utolsó intézményeit: a Legfelsőbb Tanácsot, a Népi Küldöttgyülést, a szovjethatalom helyi szerveit. A tanácsok - miután elveszítették a hatalmi harcot az elnöki struktúrákkal szemben - nem tudtak a helyi önkormányzat szerveiként érvényesülni. A függölegesen alá-fölérendelt végrehajtó hatalom bevezetése, a gazdasági fizetésképtelenség, a lakosság támogatásának hiánya, továbbá a hatalmi harc mind azt eredményezte tipikusan az Udmurt Köztársaságban, hogy a tanácsok a politikai élet perifériájára kerültek, ahol már nem tudták a mindenható intézmény szerepét eljátszani. A tanácsokat más történelmi periódusban választották, ezért nem sikerült teljes értékü képviseleti intézményekké válniuk, miután tisztán politikai funkciójukat a minimumra szorították le (Gelman 1992). Más megfogalmazásban, a hatalomszervezés szovjet modellje nem illeszkedett be az új orosz államiság gyökeres politikai és gazdasági átalakulásának stratégiájába. 


\section{Jegyzetek}

${ }^{1}$ Vedomosti Sjezda narodnych deputatov SSSR i Verchovnogo Sovjeta SSSR, 1990. No 44. St. 914.

${ }^{2}$ Vedomosti RSFSR. 1991. No 29. St. 1010, 1011.

${ }^{3}$ Archivnyj otdel administraciji g. Izevska. F. 5. Op. 1. D. 2524. L. 16., 46.

${ }^{4}$ Vedomstvennyj Archiv Gossovjeta U.R. F. R - 620. Op. 1. D. 2544. L. 24.

${ }^{5}$ Archivnyj otdel administraciji g. Uzevska. F. 5. Op. 1. D. 2432. L. 19-20.

${ }^{6}$ Archivnyj otdel administraciji g. Uzevska. F. 5. Op. 1. D. 2484. L. 2-4, 130, 225.

${ }^{7}$ Lzvesti Udmurtskoj Respubliki. 1991. 27 dekabrja. S. 1.

${ }^{8}$ Archivnyj otdel administraciji g. Izevska. F. 5. Op. 1. D 2409. L. 27.

${ }^{9}$ Vedomstvennyj Archiv Gossoveta U.R. F. R-620. Op. 1. D. 2278. L. 1-2.

${ }^{10}$ Vedomstvennyj Archiv Gossoveta U.R. F. R-620. Op. 1. D 2123. L. 83. D. 2126. L. 1, $5,7$.

${ }^{11}$ Vedomstvennyj Archiv Gossovjeta U.R. F. R-620. Op. 1. D. 2121. L. 3.

${ }^{12}$ Ivestija Udmurtskoj Resubliki. 1992. 19 marta. S. 1.

${ }^{13}$ Udmurtskaja pravda 1991. 18 maja.

\section{Irodalom}

Avakjan, S.A. (1996) Mestnoje samoupravlenije v Rossijskoj Federaciji: koncepciji i reschenija novogo zakona. - Vestnik MGU. 2.3-34. o.

Begunov, A.G.-Semjonov, Ju.V.-Schischkin, M.I. (1999) Gosudarstvennoje regulirovanije razvitja mestnogo samoupravlenija. Izevsk.

Bechterev, S.L.-Bechtereva, L.N. (2001) Konstitucionnaja reforma v Udmurtskoj Respublike (1990-2000) Rossijskaja gosudarstvennost: urovnivlasti. Teorija i praktika sovremennogo gosudarstvennogo stroitelstva. Materialy Vserossijskoj naucno-prakticeskoj konferenciji. 24-26 aprelja. Izevsk.

Frojanov, IJa. (1999) Pogruzenije v bezdnu. (Rosija na ischode XX veka). SzPb, Szentpétervár.

Gelman, V. (1992) Evoljucija predstavitelnych organov vlasti v sovremennoj Rossiji. - Politiceskij monitoring. 11. 154-176. o.

Kljamkin, I. (1999) Rossijskaja vlast na rubeze tysjaceletij. - Pro et contra.T. 4. Vesna.

Koveschnikov, Je.M. (2002) Gosudarstvo i mestnoje samoupravlenije v Rossiji: teoretiko-pravovyje osnovy vzaimodejstija.

Lukjanova, Je.A. (2000) Rossijskaja gosudarstvennost $i$ konstitucionnoje zakonodatelstvo $v$ Rossiji 1917-1993.

Materialy, I. (1991) Vsesojuznogo sjezda udmurtov. Izevsk.

Osadcij, I. (1996) Sovjety: dialektika rozvitija, priciny porazenija, - Dialog. 2. 71-77. o.

Regiony Rossiji: chronika i rukovoditeli. (2000) T. 7. Sapporo.

Ivancenko, A.V. (pod. red.) (2001) Rossijskoje narodovlastije: razvitije, sovremennyje tendenciji i protivorecija.

Rjabov, A.V. (1994) O nekotorych osobennostjach razvjortyvanija politiceskogo progressa Rossiji (1990-1994). - Vestnik MGU. (socialno-politiceskoje isslekovanije). 5. 68-81. o.

Scukin, S. (1995) Vlast $v$ zakone. Izevsk.

Terescenko, Ju.A. (1997) Reforma politiceskoj sistemy SSSR: Pricinu i posledstvija 1985-1997. Muzejnyj sbornik. 74-87. o.

Trofimova, J.N. (2002) Reforma sovjetskoj sistemy upravlenija na mestach v 99 gg. XX v. (na primere respublik Povolzja) - Istorija gosudarstva i prava. Federalnyj zurnal. Naucno-pravovoje izdanije. 4. 33-38. 0.

Udmurtija $v$ gody reform (1990-200I). (2001) Jekaterinburg.

Vojtovic, V.Ju. (2003) Gosudarstvennost Udmurtiji. Istorija i sovremennost. Izevsk.

Zakon U.P. (1991) O reforme gosudartvennoj vlasti i upravlenija v Udmurstkoj Respublike. Udmurtskaja Pravda. 17. oknjabrja. 